\title{
DON'T TELL ME WOMEN AREN'T THE STUFF OF HEROES
}

\section{MIA SANDERS}

\section{ABSTRACT}

This zine explores the intergenerational effects of my family's forced migration - from Changsha to Taipei during the Cultural Revolution, and from Taipei to Toronto after my mother was born. I grew up in a difficult household environment, in large part because of my mother's PTSD: a direct result of the trauma she has experienced throughout her lifetime in the diaspora. I now live with PTSD, as well. "Don't tell me women aren't the stuff of heroes" is a meditation on displacement from home-across generations and borders - and the experience of finding a sense of home in the people who have hurt you the most.

\section{KEYWORDS}

immigration, diaspora, intergenerational trauma, kinship, zine

\section{A C R NOW LEDGM E N T S}

Thank you Mom, Ez, Nai-Nai, and Poh-Poh for your fire and soul.

\begin{abstract}
AUTHOR BIO
Mia is a queer, mixed-race student and artist living and learning in Tkaronto/Toronto. They are curious about the relation between race and disability and are excited by the affordances of arts-based research. They

love creating things with cool people.
\end{abstract}




\section{漫 DON'T TELL ME}

云 WOMEN AREN'T 女 THE STUFF OF

子 HEROES.

A Z INE BY

孙美运 MIA SANDERS

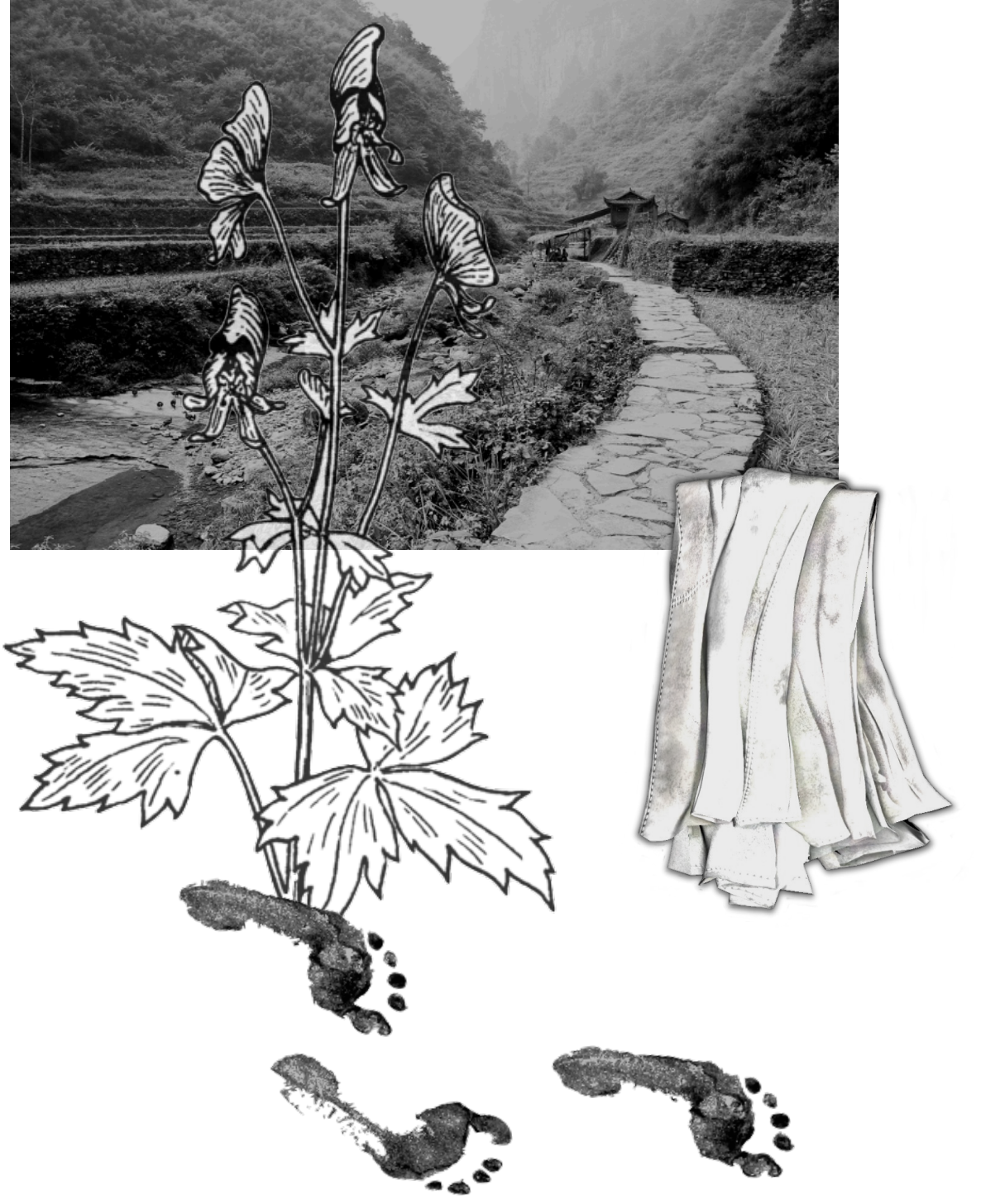

My PO-PO, YuEFEI, FIRST RAN FROM THE Tis.FOOTBINDER WHEN SHE WAS FOUR. 
DECADES LATER, WHEN THE

RED ARMY INVADED, SHE RAN AGAIN, HER FEET UNBOUND, AND NEVER LOOKED BACK.
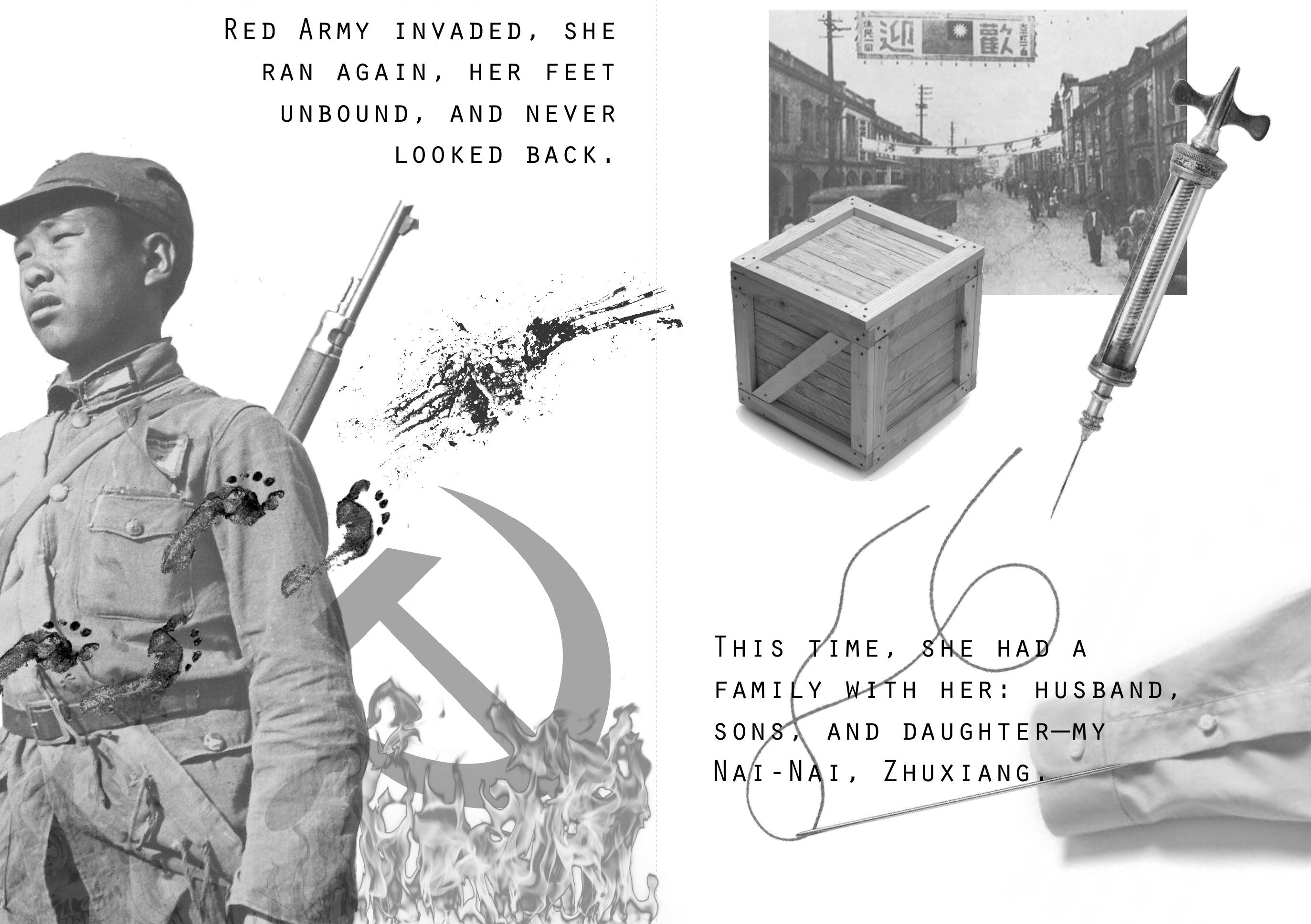


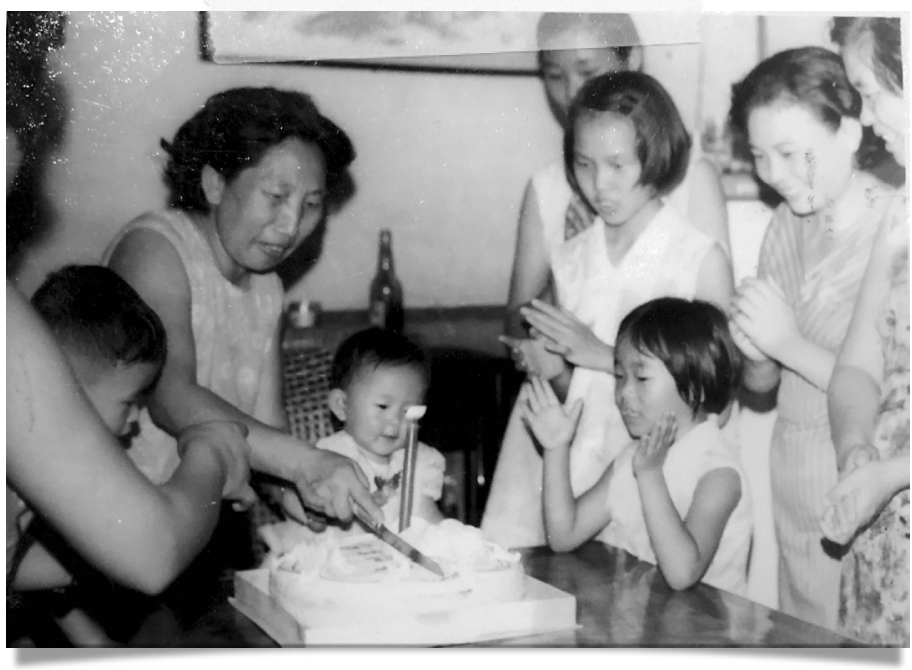

They Fled to TAipei, WHERE THEY MADE A

Life. Then my Mama, JIAHUA, WAS BORN...

BORN..
...SO THEY IMMIGRATED TO

TORONTO TO BUILD A

FUTURE FOR HER.

Po-Po, NAI-NAI, YE-YE,

AND MAMA.

THEY STARTED OUT IN REGENT PARK AND WORKED THEIR WAY TO SCARBOROUGH.
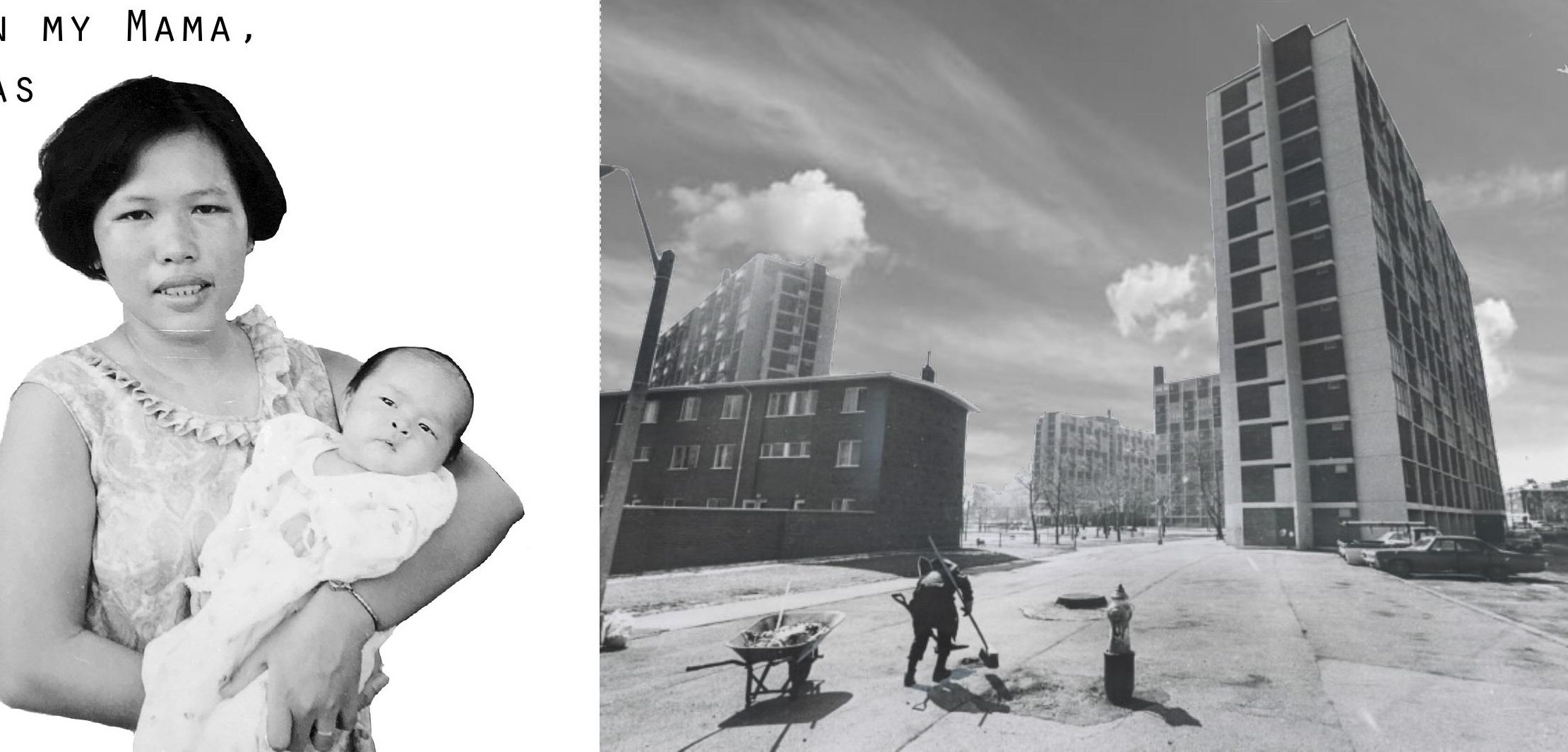
WHEN MAMA WAS OLD ENOUGH, SHE TAUGHT PO-PO ENGLISH .

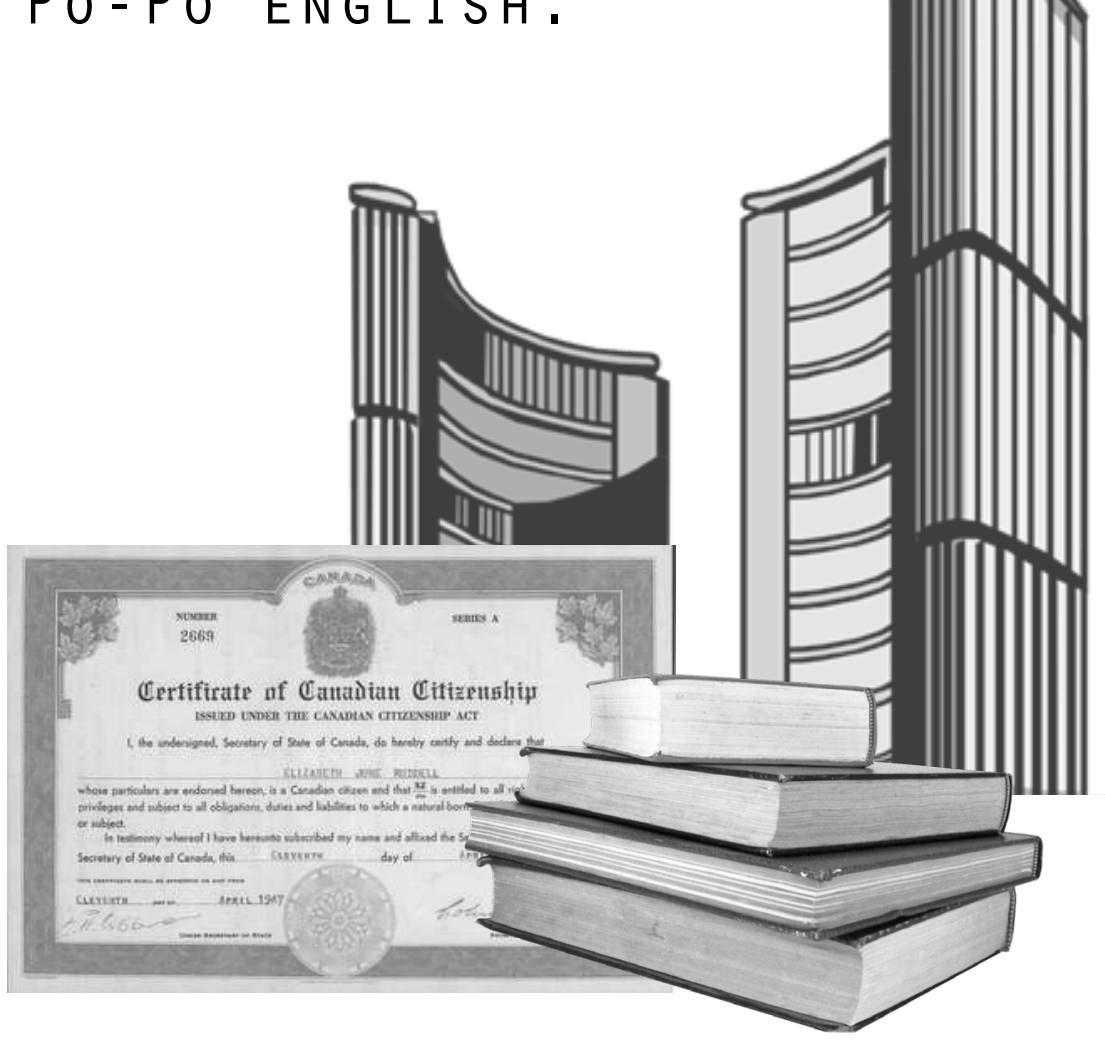

EVERY DAY SHE SAT AT THE KITCHEN TABLE AND HELPED HER PREPARE FOR HER C I T I ZENSHIP TEST .
When the Judge asked Po-Po TO IDENTIFY A PORTRAIT OF PiERRE TRUDEAU, SHE SAID: “THE QUEEN?"

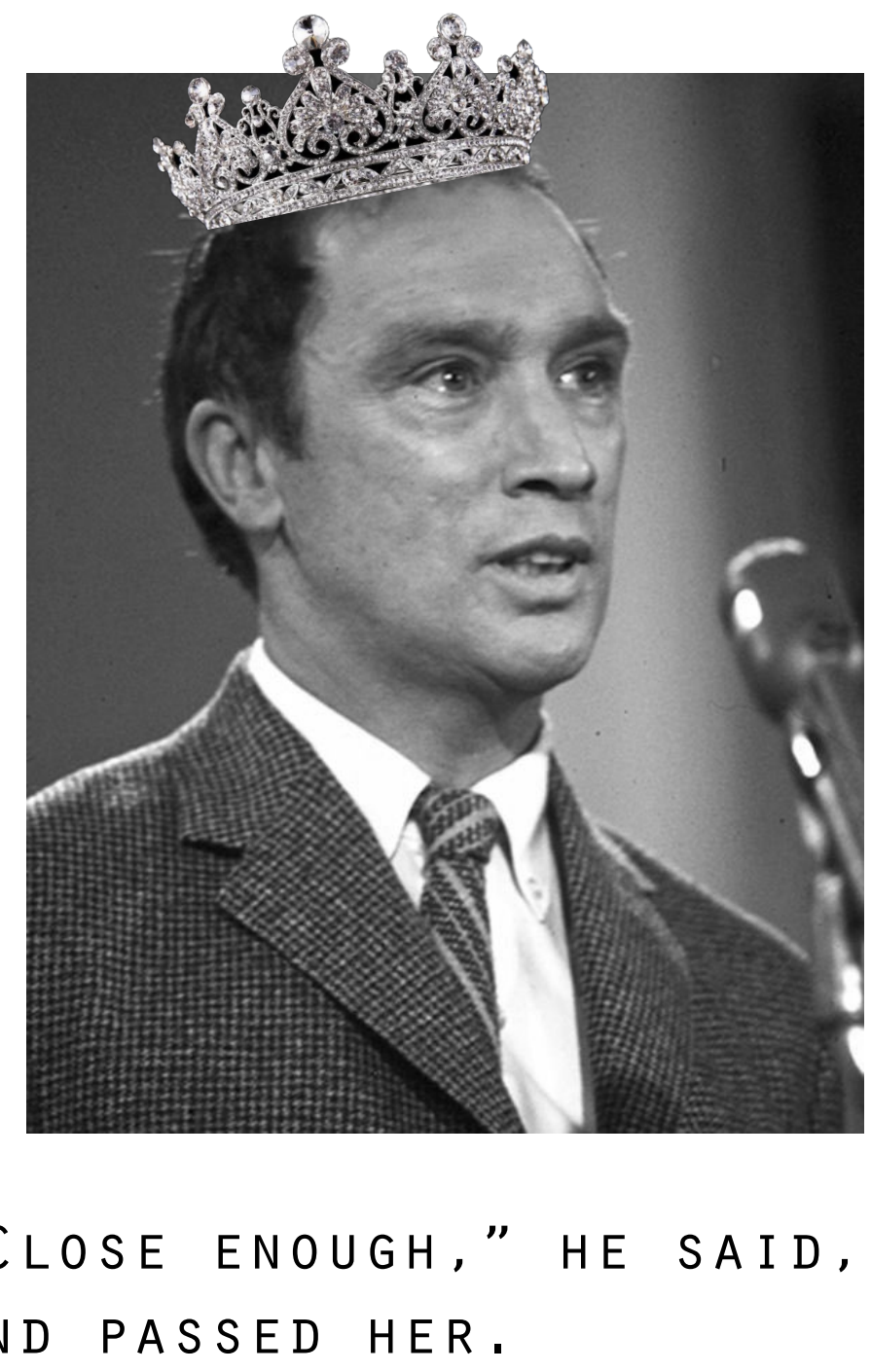


PO-PO WAS STRONG-WILLED,

LOVING, AND OPEN-MINDED,

MAMA TELLS ME.

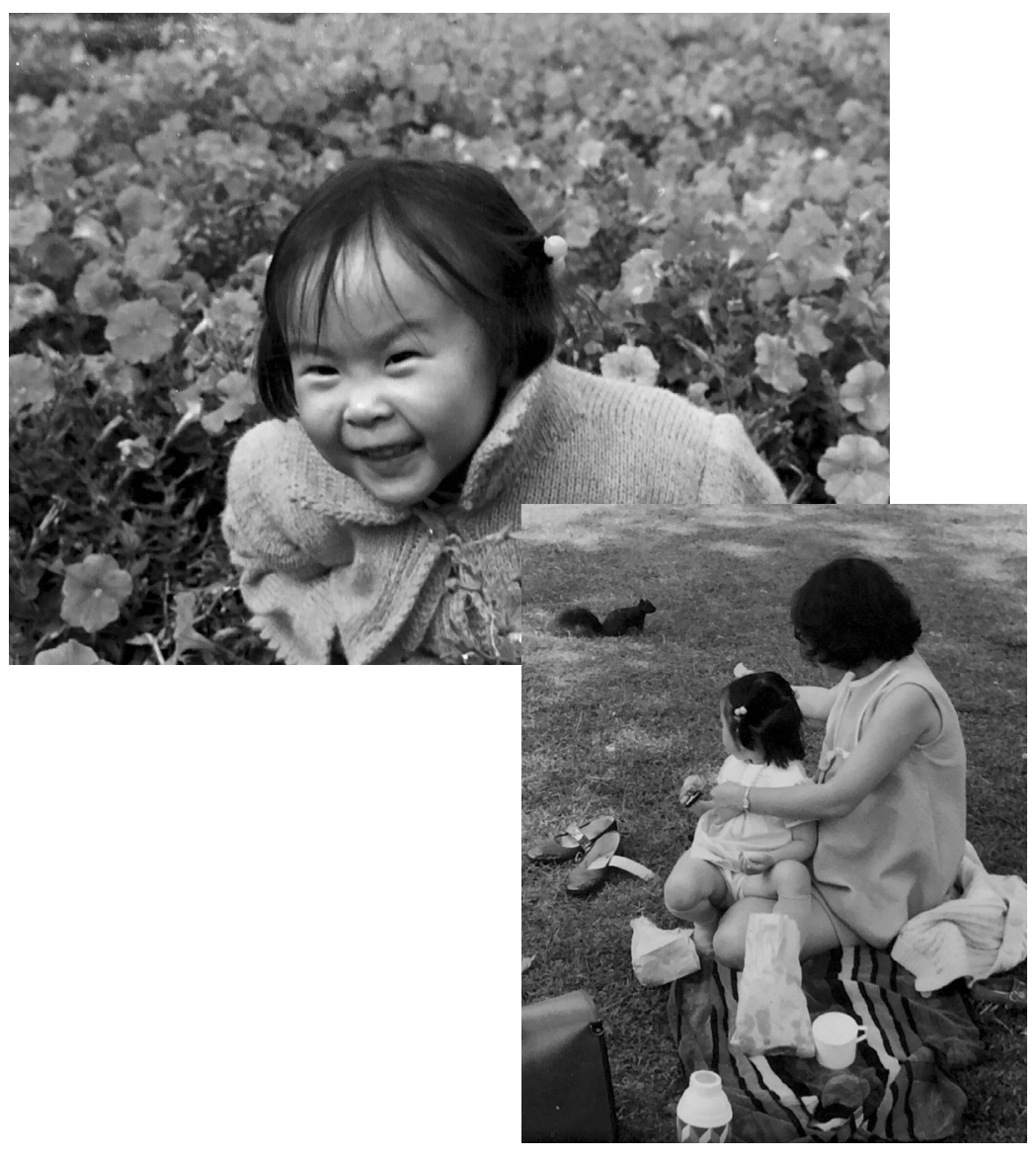

AND I T D I D.

SHE KNEW THE WORLD COULD

CHANGE ON A DIME. 
ONE NIGHT, MAMA's

FATHER/WENT ON A MI L K R U N

AND NENER CAME BACK.

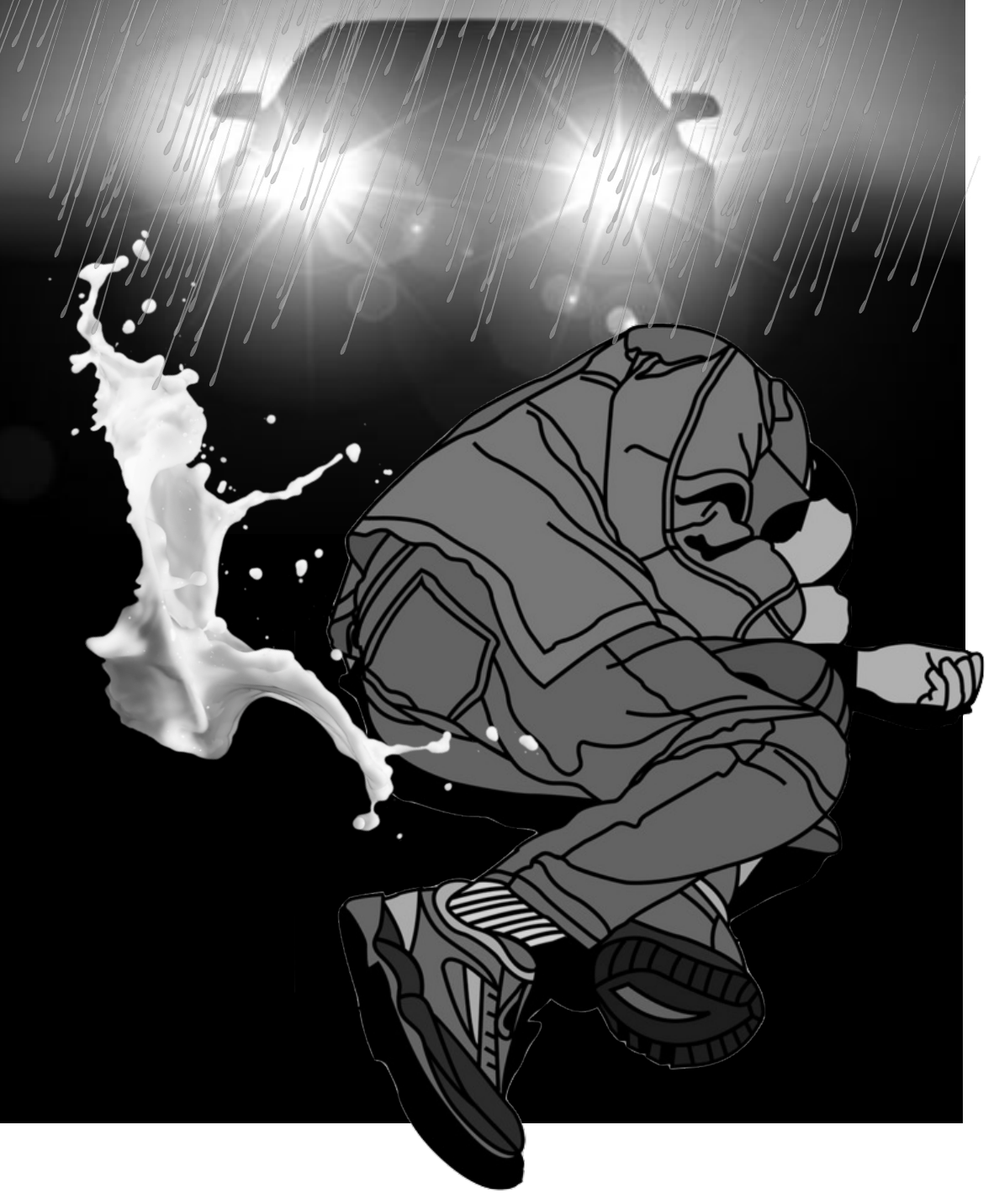

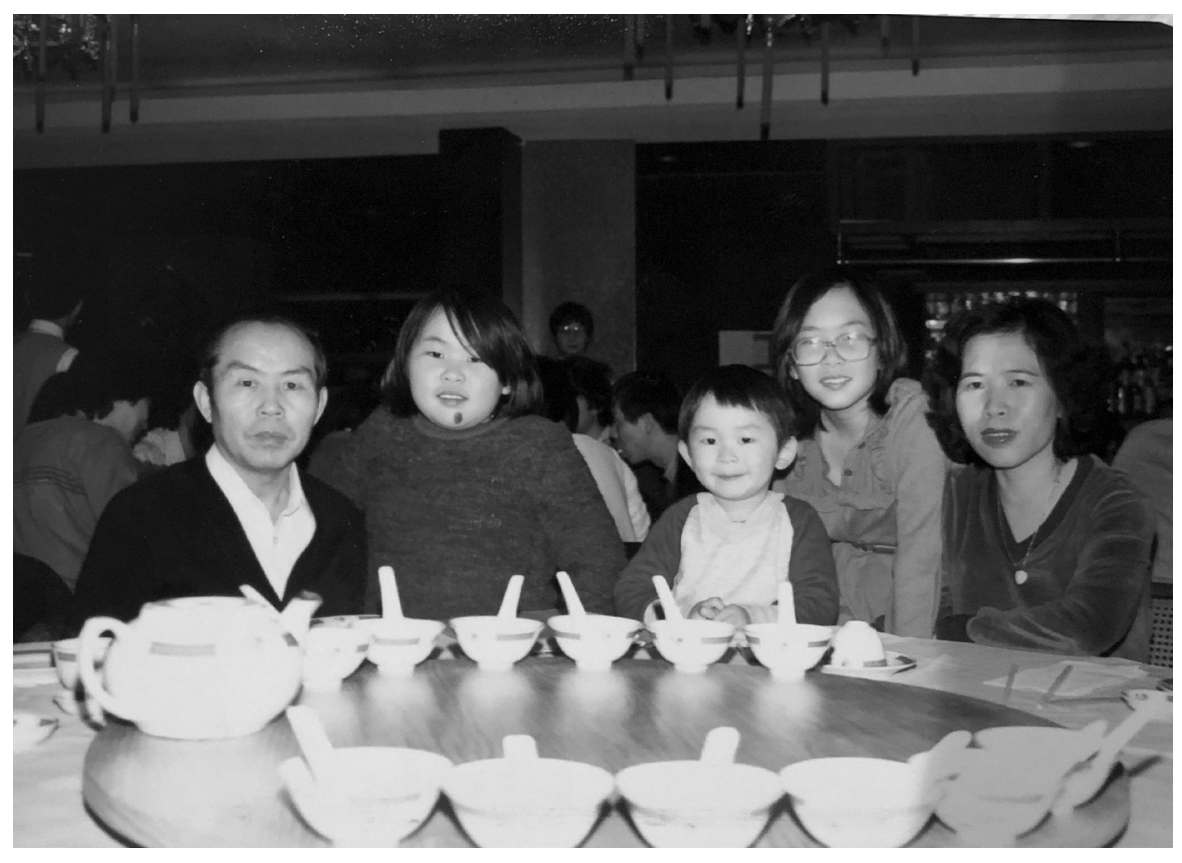

SHE WAS 12 YEARS OLD, HER SISTER WAS 8, AND HER BROTHER WAS 4 . 
NA I-NA I BECAME DEPRESSED, CATATONIC, SO MAMA BECAME THE HEAD OF THE HOUSEHOLD . SHE DID THE COOKING AND CLEANING, MANAGED THE FINANCES, WENT TO PARENT TEACHER INTERVIEWS .

SHE RAISED HER BROTHER AND SISTER, AND TENDED TO PO-PO IN HER ILL HEALTH .
MAMA WAS NEVER ONE TO CRY OVER SPILT MI LK .

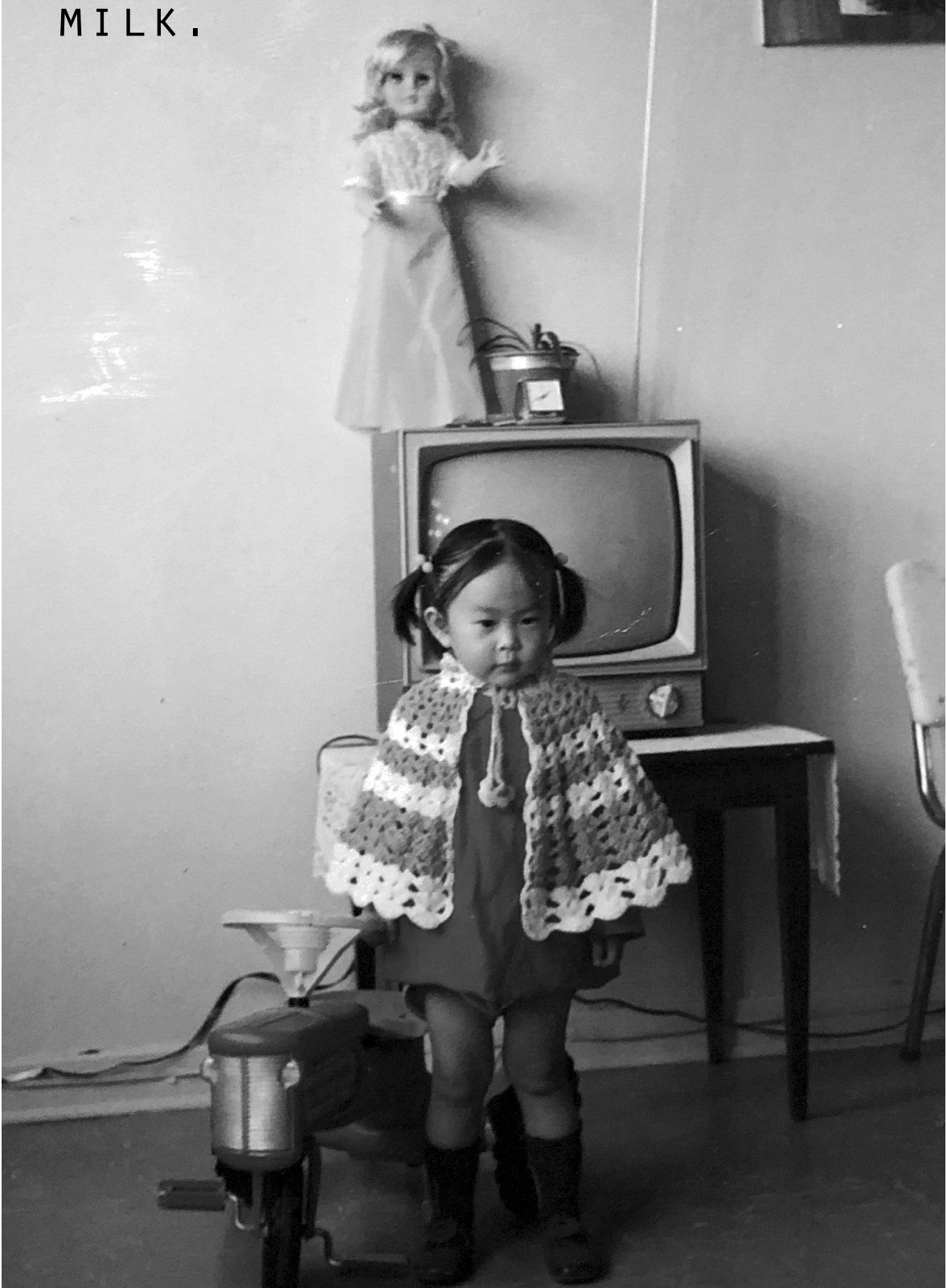




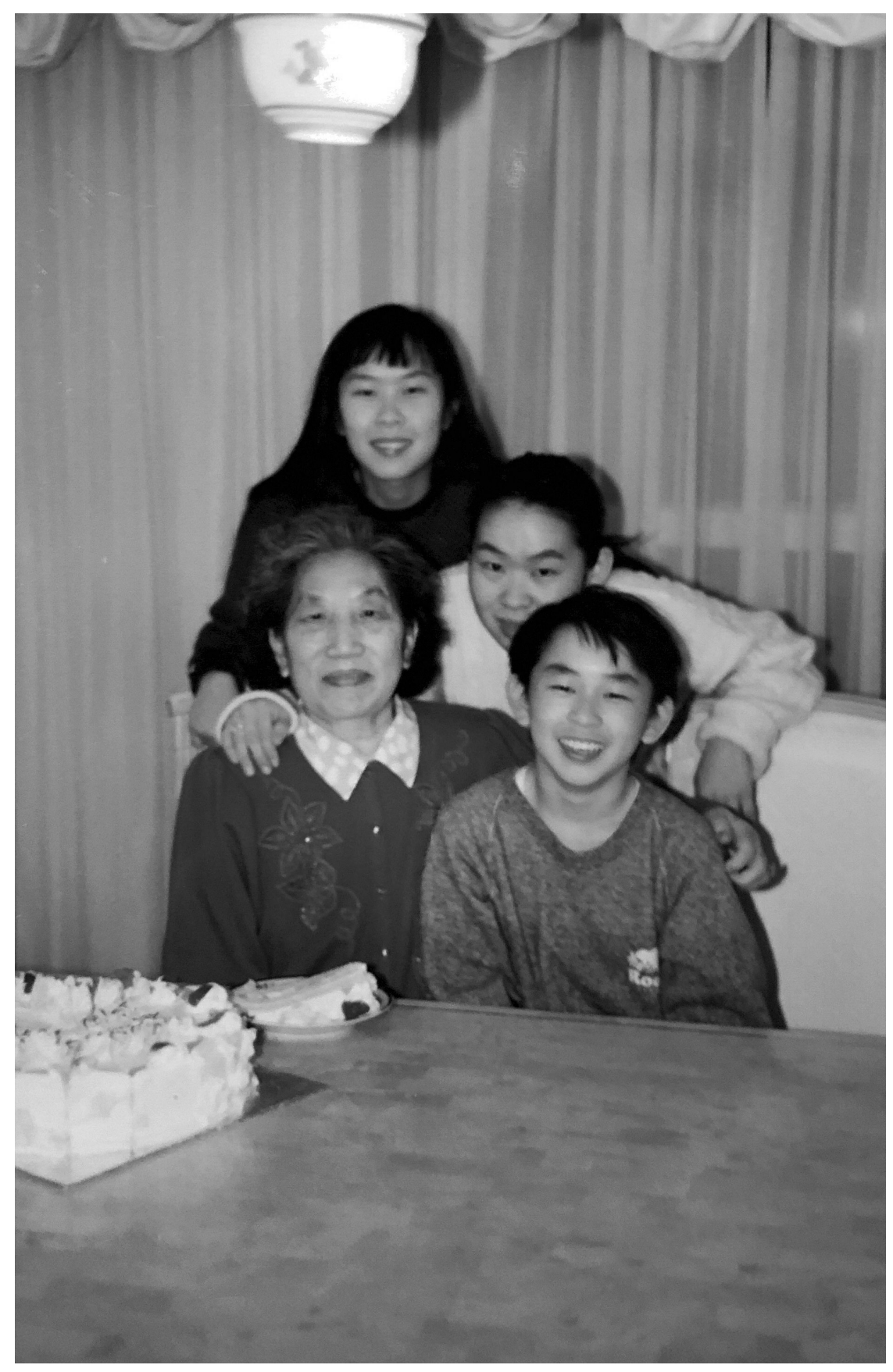

PO-Po loved Mama across seas, FROM TAIPEI TO TORONTO. THEY GREW TOGETHER， CARED FOR ONE ANOTHER, AND WHEN PO-PO WAS ON her deathbed, Mama Was the LAST ONE TO SAY 再见.

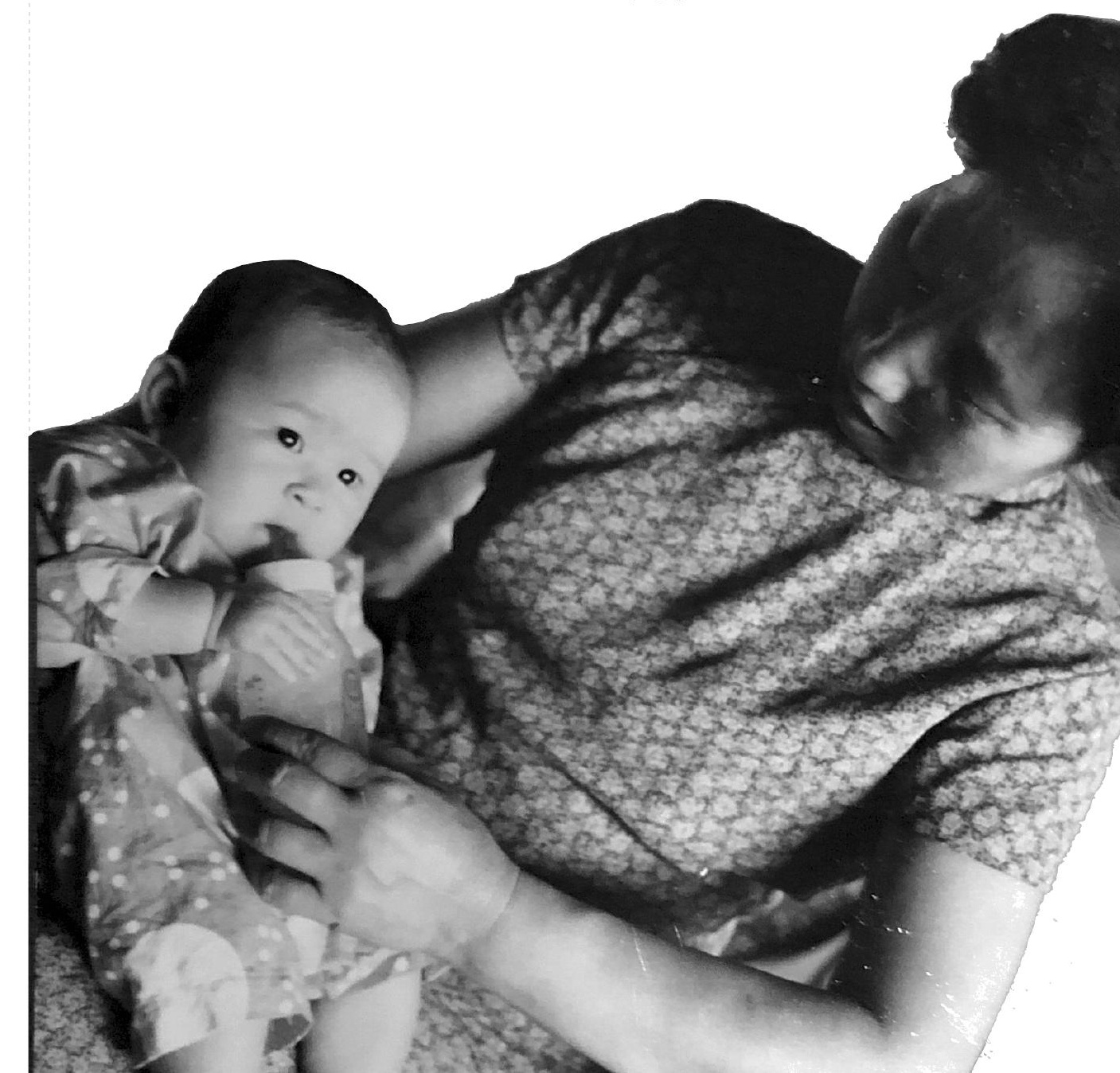


I LOVE MY MAMA SO MUCH. SHE' S MY HERO.

我爱你，妈妈。

SHE'S HURT ME SO MUCH, T 00 .

为什么, 妈妈?

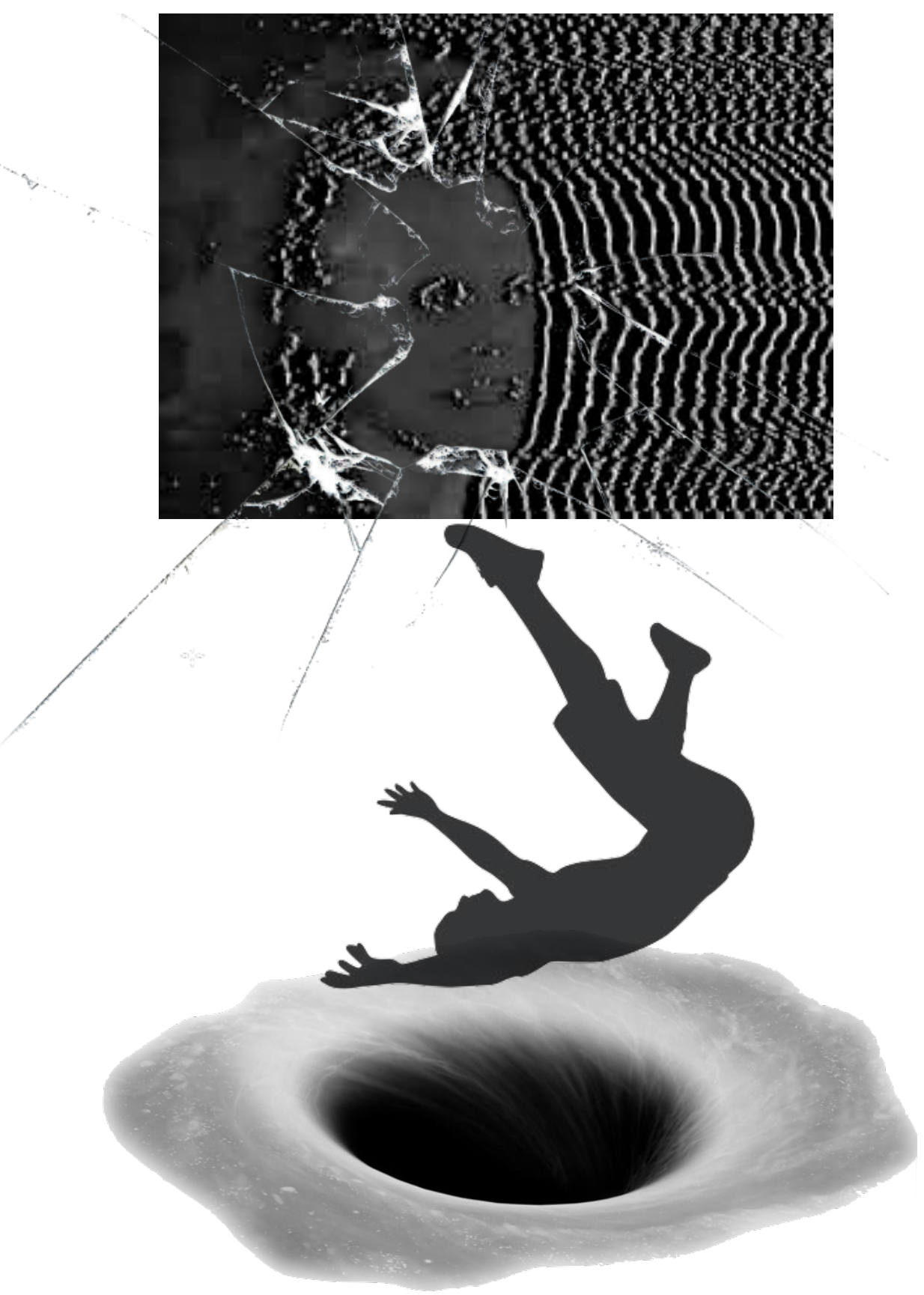




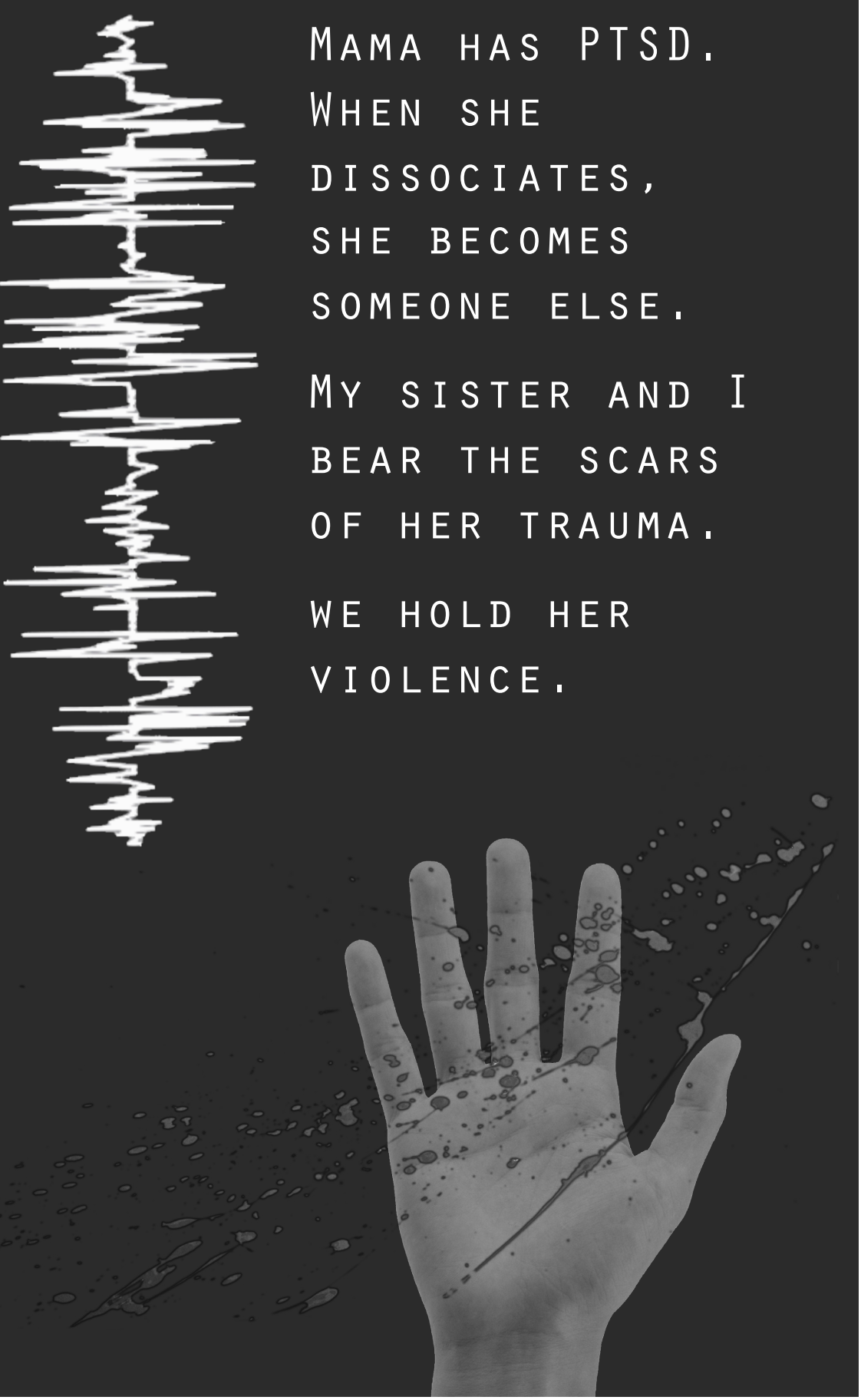

\section{AND WE HOLD EACH OTHER.}

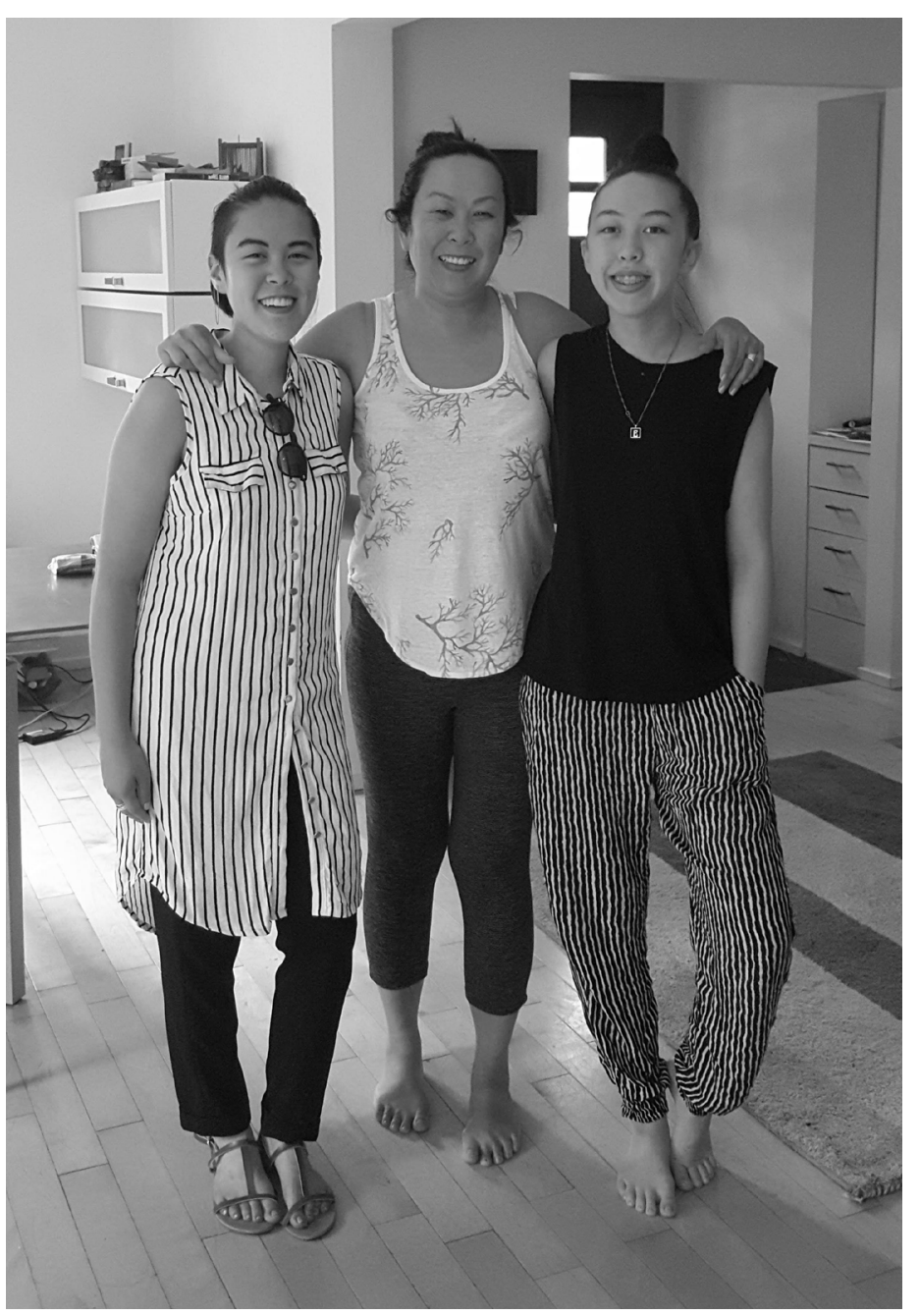




\section{漫云女子不英雄, 萬里乘風獨向東。}

詩思一帆海空闊...

...骨肉分离出玉门。

放足湔除千载毒,

热心唤起百花魂。
DON'T TELL ME WOMEN AREN'T THE STUFF OF HEROES, I ALONE RODE OVER THE EAST SEA'S WINDS FOR TEN THOUSAND LEAGUES. MY POETIC THOUGHTS EVER EXPAND, LIKE A SAIL BETWEEN OCEAN AND HEAVEN...

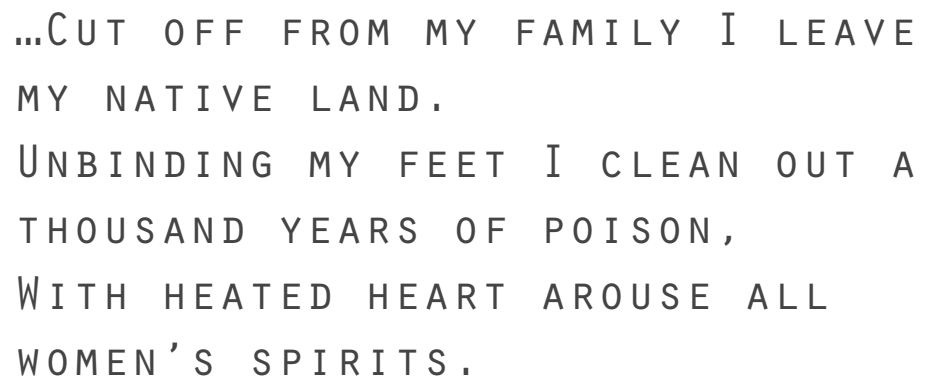

